\title{
THE REVIEW OF MEETINGS OF THE GOVERNMENT OF THE RUSSIAN FEDERATION IN JANUARY 2016
} M.Goldin

In January 2016, at the meetings of the Government of the Russian Federation the issue of development of the network of multifunctional centers (MFC) providing state and municipal services was discussed among other things.

On 14 January 2016, at the meeting of the Government of the Russian Federation the report by A. Ulyukaev, RF Economic Development Minister on development of the network of multifunctional centers providing state and municipal services was discussed.

In the report, it was pointed out that efforts by the Ministry of Economic Development of the Russian Federation to ensure availability of state services through the "single window" network were successful. So, the MFS coverage of the population stands at $94.2 \%$.

As maintenance of MFC entails serious burdens on budgets of constituent entities of the Russian Federation (regions spent Rb 34bn on establishment and maintenance of MFC), by amendment of the Budget Code of the Russian Federation, a decision on equal division of revenues received from state duties charged for provision of state services was taken and implemented, that is, all the revenues are paid to the federal and regional budgets on a fifty-fifty basis. That norm was introduced by Federal Law No. 249-FZ of 21 July 2014.

So, in 2015 the aggregate income of constituent entities of the Russian Federation from payment of state duties for provision of state services amounted to about $\mathrm{Rb} 8 \mathrm{bn}$.

Currently, the Ministry of Economic Development of the Russian Federation is studying the prospect of distributing the fee $(50 \%$ to the federal budget and $50 \%$ to regional budgets) for provision of state services by state institutions (for example, regional offices of the Federal Cadastral Chamber of the Federal State Service of Registration, Cadaster and Cartography).

Upon consideration of the above report, the Ministry of Economic Development of the Russian Federation together with the RF Ministry of Internal Affairs, the Ministry of Communications of the Russian Federation, the Federal Migration Service and other concerned executive authorities were instructed to prepare and submit to the RF Government before 15 April 2016 a draft statutory act providing for the list of state services rendered on the basis of a MFC "single window" principle to be supplemented with the following state services:

- Issuing of driving licenses in case of replacement and loss (theft) thereof and international driving licenses;

- Issuing and replacement of a passport of a RF national for identification of a RF national in the territory of the RF;

- Execution and issuing of a passport of a RF national for identification of a RF national beyond the territory of the RF;

- Execution and issuing of a passport of a RF national with electronic storage device for identification of a RF national beyond the territory of the RF and record-keeping of such passports. 
In addition to the above, the Ministry of Economic Development of the Russian Federation was instructed to expand application of the exterritoriality principle of MFC operations in all the constituent entities of the Russian Federation. 